\title{
Lipid profile and quality of meat from finishing pig supplemented with minerals
}

\author{
Tatiane Mendonça Nogueira Carneiro de ALBUQUERQUE ${ }^{1}$ (D), Eduardo Mendes RAMOS², \\ Isabella Fiche da Matta MACHADO ${ }^{1}$, Paula Caixeta BORGES ${ }^{1}$, Ana Gabriella BOLLETA ${ }^{1}$, Joanna Oliveira MARÇAL ${ }^{1}$, \\ Fernanda Paul de CARVALHO ${ }^{1}$, Peter Bitencourt FARIA ${ }^{1 *}$
}

\begin{abstract}
This study aimed evaluate the effects of the associated supplementation of: chromium more iron ( $\mathrm{CrFe})$, magnesium more selenium (MgSe) and the four minerals $(\mathrm{CrFeMgSe})$ on the parameters related to the pork quality. Supplementation with MgSe reduced the ether extract of the meat and changed the fatty acids profile, increasing the poly-unsaturated, $n-3, n-6$, the polyunsaturated: saturated rate and the activity of the enzyme Thioesterase index, besides reducing the total number of saturated fatty acids and the Atherogenicity index. It promoted a reduction in $\mathrm{a}^{\star}, \mathrm{b}^{*}$ and $\mathrm{C}^{*}$ indices and increased $\mathrm{h}^{*}$ of the chilled meat stored. Over the storage days under refrigeration, there was linear drop for $\mathrm{L}^{\star}$ and $\mathrm{a}^{\star}$ and an increase to $\mathrm{C}^{\star}$. The associated use of magnesium and selenium promotes changes in lipid profile without changing the meat quality, and they may be used in order to obtain meat with more appropriate nutritional aspects.
\end{abstract}

Keywords: chromium; fatty acid; iron; magnesium; selenium.

Practical application: Magnesium and selenium reduce the saturated fatty acid and increase n-3 levels of the pork.

\section{Introduction}

Pork represents the largest source of animal protein consumed globally and the demand for this product grows each day (United States Department of Agriculture, 2018). However, consumers have become more demanding in relation to the quality of the pork and the inherent health benefits it can provide. To meet this demand, nutritional strategies applied during the animals production, arise as a tool to improve the meat quality characteristics, as well as to reduce the fat content, making it leaner and with a lipid profile better suited for consumption as recommended by the World Health Organization (Food and Agriculture Organization of United Nations, 2010).

Supplementation with minerals such as chromium and magnesium, can contribute to an increase in the amount of tissue muscle and reduction of the fat deposition in the meat due to the effect of the nutrients repartition, which act on the carbohydrates and lipids metabolism (Apple et al., 2000). Magnesium supplementation pre-slaughter has also been shown to reduce the effects of stressors, reducing the catecholamines and cortisol levels release, muscle relaxation and reduced neuromuscular stimulation, preventing the sudden drop in muscle $\mathrm{pH}$ post-slaughter, reduces the $\mathrm{L}^{*}$ indices (Swigert et al., 2004), affect the activity of the enzyme $\Delta-6$ desaturase, participating in the metabolism of long-chain fatty acids, and it may increase the levels of fatty acids $n$-3 in the meat (Mahfouz \& Kummerow, 1989).

Currently, due to the genetic breeding focused on increasing lean tissue and predominance of polyunsaturated fatty acids, pork has become pale. This, combined with a higher propensity to lipid oxidation and hence of the pigments of such meat, favor the loss of color and an unpleasant aspect to the consumer during its frozen exposure. Thus, the swine's supplementation with iron can increase the iron-heme levels in the muscle (Yu et al., 2000), an integral part of the pigment myoglobin, promoting improvement in the meat color, turning it redder and more intense. In addition, the supplementation with Selenium can contribute for a better meat stability due to its protective action in the membranes, preserving it against the oxidizing agents (Calvo et al., 2016). The color of the pigment myoglobin is also dependent on the lipid oxidation degree in the meat (Apple et al., 2007).

The studies reported in the literature relate to the supplementation with these minerals in isolation and many of these are in their inorganic sources, which has a lower bioavailability. The aim of this study was to verify the influence of supplementation associated with organic sources of chromium, iron, magnesium and selenium, on the physical and chemical properties and centesimal composition of pork from finishing pig.

\section{Material and methods}

\subsection{Experiment design and diet}

For the experiment, 44 barrows were used (crossbreeding between DanBred females - DB90 $\times$ males PIC - AGPIC337), with an average weight of $81.6 \pm 5.22 \mathrm{~kg}$, housed in finishing swine-house, with concreted floor pens $(2.3 \times 1.5 \mathrm{~m})$, with semi-automatic feeders and nipple type waterer. The total experimental period was 28 days. The experimental design was in randomized complete block design (RCBD), according to the 
live weight, with four treatments (diets) and 11 repetitions with each experimental plot represented by an animal.

The diets were formulated based on corn, soybean meal, vitamins and minerals, amino acids, and ractopamine, formulated to meet the minimum requirements of finishing pigs and supplemented with chromium, iron, magnesium and selenium from organic source (Biometa ${ }^{\circledR}, \mathrm{NPA}$ - Núcleo de Pesquisas Aplicadas Ltda, Jaboticabal, SP, Brazil), being the minerals included replacing kaolin (Table 1). The animals were randomly divided into four groups, receiving the following treatments: 1 ) Control: basal diet for 28 days; 2) CrFe: basal diet $+400 \mathrm{ppb}$ of chromium and $100 \mathrm{ppm}$ of iron during 28 days; 3$) \mathrm{MgSe}$ : basal diet for 28 days $+300 \mathrm{ppm}$ of magnesium and $3 \mathrm{ppm}$ of selenium in the last seven days; 4) CrFeMgSe: basal diet $+400 \mathrm{ppb}$ of chromium

Table 1. Composition of basal diet provided to animals during the termination period.

\begin{tabular}{|c|c|}
\hline Ingredients & $\mathrm{kg}$ per $100 \mathrm{~kg}$ of diet ${ }^{\star}$ \\
\hline Corn & 75.70 \\
\hline Soybean meal & 20.00 \\
\hline Soybean oil & 1.00 \\
\hline Dicalcium Phosphate & 0.77 \\
\hline Limestone & 0.56 \\
\hline Salt & 0.35 \\
\hline Premix Mineral $^{1}$ & 0.18 \\
\hline Premix Vitaminic ${ }^{2}$ & 0.30 \\
\hline L- Lysine $50,7 \%$ & 0.47 \\
\hline DL- Methionine 99\% & 0.09 \\
\hline L- Threonine 98\% & 0.10 \\
\hline Ractopamine & 0.05 \\
\hline Kaolin** & 0.45 \\
\hline Iron $^{3}$ & $6.12 \times 10^{-4}$ \\
\hline Chromium $^{4}$ & $3.4 \times 10^{-6}$ \\
\hline Magnesium $^{5}$ & $3.22 \times 10^{-3}$ \\
\hline Selenium $^{6}$ & $3.06 \times 10^{-4}$ \\
\hline TOTAL & 100.00 \\
\hline \multicolumn{2}{|l|}{ Calculated nutritional values } \\
\hline Crude protein (\%) & 15.01 \\
\hline Metabolizable energy $(\mathrm{kcal} / \mathrm{kg})$ & 3240 \\
\hline Calcium (\%) & 0.47 \\
\hline Available phosphorus (\%) & 0.23 \\
\hline Sodium (\%) & 0.16 \\
\hline Digestible Lysine (\%) & 0.88 \\
\hline Digestible methionine (\%) & 0.31 \\
\hline Methionine + Cystine (\%) & 0.54 \\
\hline Digestible threonine (\%) & 0.61 \\
\hline
\end{tabular}

${ }^{*}$ Diets: 1) Control: basal diet without mineral supplementation; 2) CrFe: basal diet supplemented with $3.4 \mathrm{mg} / \mathrm{kg}$ of $\mathrm{Cr}$ and $612.4 \mathrm{mg} / \mathrm{kg}$ of Fe; 3) MgSe: basal diet supplemented with $3215.4 \mathrm{mg} / \mathrm{kg}$ of $\mathrm{Mg}$ and $306.1 \mathrm{mg} / \mathrm{kg}$ of Se; 4) CrFeMgSe: basal diet supplemented with $3.4 \mathrm{mg} / \mathrm{kg}$ of Cr, $612.4 \mathrm{mg} / \mathrm{kg}$ of Fe, $3215.4 \mathrm{mg} / \mathrm{kg}$ of $\mathrm{Mg}$ and $306.1 \mathrm{mg} / \mathrm{kg}$ of Se. ${ }^{* *}$ the minerals were included in place of kaolin. ${ }^{1}$ Composition per $\mathrm{kg}$ of product: cobalt, $299.7 \mathrm{mg}$; copper, $9.000 \mathrm{mg}$; iron, $48 \mathrm{~g}$; iodine, $659.7 \mathrm{mg}$; manganese, $21 \mathrm{~g}$; zinc, $78.3 \mathrm{~g}$; selenium, $240.3 \mathrm{mg} ;{ }^{2}$ Composition per $\mathrm{kg}$ of product: folic acid, $144 \mathrm{mg}$; pantothenic acid, $2.160 \mathrm{mg}$; biotin, $21.60 \mathrm{mg}$; niacin, $3.960 \mathrm{mg}$; choline, $36.02 \mathrm{~g}$; Vit. A, 1.440.000 U.I.; Vit.B1, 288 mg; Vit.B12, 3.960 mcg; Vit.B2, 720 mg; Vit.B6, 540 mg; Vit. D3, 540.000 U.I.; Vit. E, 7.200 U.I.; Vit. K3, 540 mg. ${ }^{3}$ Biometal Chromium ${ }^{\circledR}$ : chromium picolinate $(11.68 \%$ of $\mathrm{Cr}) ;{ }^{4}$ Biometal Iron ${ }^{\circledR}: 16.33 \%$ of $\mathrm{Fe}$; ${ }^{5}$ Biometal magnesium ${ }^{\circledR}$ : magnesium bisglycinate $(9.33 \% \mathrm{Mg}) ;{ }^{6}$ Biometal selenium ${ }^{\circledast}$ : selenium glycinate $(0.98 \% \mathrm{Se})$ L: levorotatory monomer; DL: racemic mixture of monomers. and $100 \mathrm{ppm}$ of iron during 28 days $+300 \mathrm{ppm}$ of magnesium and 3 ppm of selenium in the last seven days.

Food and water were provided ad libitum daily and at the end of the experiment, animals were slaughtered with an average weight of $111.55 \pm 9.53 \mathrm{~kg}$, after 12 hours of rest and fasting, in commercial slaughterhouse according to current standards.

\subsection{Physical and chemical parameters}

At the time of the slaughter, $\mathrm{pH}$ and initial temperature were measured at 45 minutes post-slaughter in the Longissimus thoracis muscle (LT) of left half carcasses, at the 12th rib height, using a stem digital thermometer and $\mathrm{pHmeter}$ with penetration probe (Hanna Instruments, HI 99163, Romania). The carcasses were kept in a chiller for $24 \mathrm{~h}$. The temperature and the final $\mathrm{pH}$ were measured again and a portion of the LT muscle was removed for the evaluations of physical and chemical parameters, centesimal composition and lipid profile.

The objective evaluation of the muscle color was performed at 24 hours post mortem, using a colorimeter (Konica Minolta CM-700, Singapore), operating in the system CIELAB, with illuminant D65, observer angle of $10^{\circ}$ and Specular Component Excluded, (SCE), to obtain the indices of luminosity $\left(\mathrm{L}^{*}\right)$, red $\left(\mathrm{a}^{\star}\right)$, yellow $\left(\mathrm{b}^{*}\right)$, oxygen saturation $\left(C=\left(a^{*^{2}+b^{* 2}}\right)^{1 / 2}\right)$ and tonality angle $\left(h^{*}=\tan ^{-1}\left(b^{*} / a^{*}\right)\right.$, in degrees), according Ramos \& Gomide (2012). The percentages of metmyoglobin $(\mathrm{MMb})$, reduced myoglobin $\left(\mathrm{Mb}^{+}\right)$and oxymyoglobin $\left(\mathrm{O}_{2} \mathrm{Mb}\right)$, were also calculated using the following equations: $M M b=1.395-\left(\left(A^{572}-A^{730}\right) /\left(A^{525}-A^{730}\right)\right)$, $M b=2.375 \times\left(1-\left(\left(A^{473}-A^{730}\right) /\left(A^{525}-A^{730}\right)\right)\right)$ and $O_{2} M b=1-\left(M M b+M b^{+}\right)$, respectively, according to the methodology of Krzywicki (1979). Visual assessment of color and marbling was conducted by five evaluators through comparison with a standard National Pork Producers Council (National Pork Producers Council, 1999) and meat pigment content by the equation: $\left(3.249 \times\left(A^{409}-\left(2.68 * A^{730}\right)\right)\right)$ according to Ramos \& Gomide (2012).

The determination of the drip loss was made by the suspension method for 48 hours, being expressed as a percentage of the initial weight, according to Honikel (1998). The cooking loss, also expressed as a percentage of the initial weight, was made involving the samples in aluminum foil and broiled on a preheated electric grill (Mega Grill; Britânia, Curitiba, PR, Brazil), to an internal temperature of $72^{\circ} \mathrm{C}$, according to methodology described by Ramos \& Gomide (2012).

The analysis of shear force was performed based on methodology by Silva et al. (2015), using six square cross-section cores with $1.0 \mathrm{~cm} \times 1.0 \mathrm{~cm}$ and the samples cross-cutting sectioned through Warner Bratzler probe coupled to a texturometer (Extralab, TA.XT Plus, UK) and the shear force expressed in Newtons (N).

The centesimal composition was assessed according to the methodology of the Association of Official Analytical Chemists (Horwitz, 1990). The moisture content was determined by oven-dried the samples at $105^{\circ} \mathrm{C}$ for 24 hours and ether extract was determined by Soxhlet extractor and results expressed as a percentage of the initial weight of sample. The amount of protein in the samples was determinate by digestion, distillation and titration with $\mathrm{HCl}$ of the samples, being 
expressed in percentage of protein calculated by the equation: $\%$ protein $=((0.02 \times 14 \times f c \times 100) /$ sample weight $) \times 6.25$. The ashes amount was assessed through dry ashing procedures in muffle furnace at $550{ }^{\circ} \mathrm{C}$, being the ash content expressed on initial weight of sample.

\subsection{Retail display}

For evaluation of retail display, steaks of $2.5 \mathrm{~cm}$ in thickness were stored in polypropylene trays, covered with film of polyvinyl chloride (PVC) permeable to oxygen and they were kept frozen $\left(4{ }^{\circ} \mathrm{C}\right)$, under constant light (24 watts), for six days. Along this period of time, the CIELAB color indexes were measured daily, and the readings were performed through the PVC film.

\subsection{Lipid profile}

The analysis of the composition of the meat fatty acids and cholesterol was performed by the extraction method described by Folch et al. (1957) and esterification by Hartman \& Lago (1973). The extracts for fatty acids profile were subjected to gas chromatography in Shimatzu chromatograph GC 2010 (Agilent Technologies Inc., Palo Alto, CA, USA) equipped with a flame ionization detector, split injector at the rate of 1:50 and capillary column of Supelco SP ${ }^{\text {TM }}-2560,100 \mathrm{~m} \times 0.25 \mathrm{~mm} \times 0.20 \mu \mathrm{m}$ (Supelco Inc., Bellefonte, PA, USA). The chromatographic conditions were initial temperature of the column of $140^{\circ} \mathrm{C} / 5$ minutes; increased $4{ }^{\circ} \mathrm{C} /$ minute to $240{ }^{\circ} \mathrm{C}$ and kept for 30 minutes, amounting to 60 minutes. The injector temperature was $260^{\circ} \mathrm{C}$. Helium was the carrier gas utilized (Faria et al., 2015). The identification of fatty acids was carried out through comparison with the retention times presented by the standard chromatogram Supelco $^{\mathrm{TM}} 37$ FAME mix (Supelco Inc., Bellefonte, PA, USA) and expressed in percentage of total fatty acids identified and subsequently grouped into: total saturated fatty acids (SFA), total monounsaturated fatty acids (MUFA), total polyunsaturated fatty acids (PUFA), total fatty acids omega $6(n-6)$ and omega 3 $(n-3)$ and their connections. The activities of the enzymes $\Delta^{9}$ desaturase, elongase and thioesterase were estimated according to Malau-Aduli et al. (1998) and Kazala et al. (1999) through the following equations: $\Delta^{9}-$ desaturase $C^{16}$ enzyme activity index $=$ $100[(C 16: n 7) /(C 16: \ln 7+C 16: 0)] ; \Delta^{9}-$ desaturase $C^{18}$ enzyme activity index $=$ $100[(C 18: \ln 9 c) /(C 18: \ln 9 c+C 18: 0)] ; C^{16}$ a $C^{18}$ elongase enzyme activity index $=$ $100[(C 18: 0+C 18: \ln 9 c) /(C 16: 0+C 16: \ln 7+C 18: 0+C 18: \ln 9 c)] ;$ $C 16$ a C14 thioesterase enzyme activity index $=100[(C 16: 0) /(C 16: 0+C 14: 0)]$. Still, the atherogenicity and thrombogenicity indices were calculated, considered as indicators of health, related to the risk of cardiovascular disease, according to Ulbricht \& Southgate (1991). The cholesterol content in its turn was quantified by colorimetric method, described by Bragagnolo \& Rodriguez-Amaya (2002), and the results were expressed in $\mathrm{mg} / 100 \mathrm{~g}$ of meat.

\subsection{Statistical analysis}

All the measured variables were tested for normality by Shapiro-Wilk Test, and those that did not show normal distribution were transformed by the procedure RANK of SAS (SAS 9.3 Intit. Inc., Cary, NC, USA). PROC RANK with NORMAL option was used to produce a transformed standard variable. All data were submitted to analysis of variance ANOVA, being that the variables that showed significant differences at a level of significance of $5 \%$ of probability, were submitted to the Tukey's test and regression for quantitative variables.

\section{Results and discussion}

\subsection{Physical-chemical characteristics}

The supplementation with different minerals did not influence the values of $\mathrm{pH}$ and initial temperature (45 minutes) and final (24 hours post mortem), cooking loss and shear force (Table 2).

Table 2. Evaluation of the physical-chemical parameters and centesimal composition of the Longissimus thoracis (LT) muscle of finishing swines supplemented with different associations between minerals.

\begin{tabular}{|c|c|c|c|c|c|}
\hline \multirow{2}{*}{ Parameters } & \multicolumn{4}{|c|}{ Diets } & \multirow{2}{*}{$P$-value } \\
\hline & Control $^{1}$ & $\mathrm{CrFe}^{2}$ & $\mathrm{MgSe}^{3}$ & $\mathrm{CrFeMgSe}^{4}$ & \\
\hline \multicolumn{6}{|l|}{ Physicochemical } \\
\hline Initial pH & $6.58 \pm 0.23$ & $6.35 \pm 0.34$ & $6.51 \pm 0.30$ & $6.37 \pm 0.25$ & 0.16 \\
\hline Initial temperature $\left({ }^{\circ} \mathrm{C}\right)$ & $36.73 \pm 2.00$ & $38.09 \pm 1.45$ & $36.50 \pm 1.86$ & $36.91 \pm 1.81$ & 0.18 \\
\hline Final temperature $\left({ }^{\circ} \mathrm{C}\right)$ & $10.96 \pm 0.77$ & $10.59 \pm 1.04$ & $10.57 \pm 0.82$ & $10.42 \pm 1.29$ & 0.55 \\
\hline Shear force $(\mathrm{N})$ & $70.58 \pm 1.04$ & $68.92 \pm 1.36$ & $69.05 \pm 1.22$ & $76.13 \pm 1.36$ & 0.48 \\
\hline Subjective marbling ${ }^{6}$ & $2.41 \pm 0.66$ & $2.25 \pm 0.52$ & $2.04 \pm 0.27$ & $1.96 \pm 0.44$ & 0.11 \\
\hline Subjective color ${ }^{6}$ & $2.95 \pm 0.18$ & $2.98 \pm 0.53$ & $3.34 \pm 0.74$ & $2.83 \pm 0.41$ & 0.14 \\
\hline Total pigments (mg/g) & $0.73 \pm 0.26$ & $0.75 \pm 0.13$ & $0.81 \pm 0.20$ & $0.67 \pm 0.12$ & 0.42 \\
\hline \multicolumn{6}{|l|}{ Centesimal composition } \\
\hline Moisture (\%) & $72.95 \pm 1.85$ & $72.73 \pm 1.15$ & $73.04 \pm 1.98$ & $72.30 \pm 1.87$ & 0.76 \\
\hline
\end{tabular}

${ }^{1}$ Control: basal diet; ${ }^{2} \mathrm{CrFe}$ : supplementation with chromium and iron; ${ }^{3} \mathrm{MgSe}$ : supplementation with magnesium and selenium; ${ }^{4} \mathrm{CrFeMgSe}$ supplementation with chromium, iron, magnesium and selenium; ${ }^{5}$ Tukey's test $(\alpha=0.05)$; ${ }^{6}$ Evaluated by comparison with standard National Pork Producers Council (1999) ranging from 1 (pale pinkish gray to white) to 6 (dark purple red) for color and from 1 (light) to 10 (abundant) for marbling; ${ }^{\text {a,b,c: }}$ : Different letters indicate statistically significant differences between treatments. Number of replicates per parameters $=11$. 
The results found in the literature regarding the supplementation with chromium, magnesium and selenium in general, did not influence the $\mathrm{pH}$ values of the meat (Frederick et al., 2006; Jin et al., 2018; Peres et al., 2014; Wojtasik-Kalinowska et al., 2018), although other studies indicated an improvement with the use of magnesium (Swigert et al., 2004).

The drip loss at 48 hours was lower $(p=0.013)$ for the animals' meat that received MgSe than those supplemented with $\mathrm{CrFe}$, however, both groups did not differ from the control group and this presented similar means to CrFeMgSe (Table 2). Khan et al. (2018) demonstrated that supplementation of broilers with $0.30 \mathrm{mg} \mathrm{Se} / \mathrm{kg}$ in the form of sodium selenite, increased the water hold capacity and the glutathione peroxidase (GSH-Px) activity. Selenium is an integral part of various selenoproteins, and it is possible to mention the selenoprotein W ( Sel W) which has demonstrated present antioxidant activity dependent on GSH-Px and contrary to the other selenoproteins, its expression in the muscle is increased even in cases of excessive selenium consumption (Jeong et al., 2004). In a study carried out by Li et al. (2011), the supplementation with selenium (0.3 and $3 \mathrm{mg} / \mathrm{kg}$ ) promoted an increase of gene expression Sepw1 related to Sel $\mathrm{W}$ and, it was shown a high and negative correlation $(-0.90)$ between the expression of this gene and the weight drop loss, and this is the crucial point of improvement in water retention capacity in the meat. In addition to selenium, magnesium has also contributed to the reduction of water loss by the meat (Lisiak et al., 2014), indicating the use of these minerals as an alternative therapy in reducing the PSE occurrence.

The scores of subjective colors and the values of total pigments were not influenced by the supply of minerals, as well as the marbling (Table 2). Similar results were found by Apple et al. (2007) working with iron and Tarsitano et al. (2013) evaluating the supplementation with magnesium.

The levels of moisture, protein and ash content were not altered in function of the treatments (Table 2). On the other hand, the percentage of ether extract was lower $(p=0.01)$ for the group that received $\mathrm{MgSe}$ compared to the control group. The group $\mathrm{CrFeMgSe}$ did not differ between the groups $\mathrm{MgSe}$ and $\mathrm{CrFe}$ and the latter was similar to the control group. The reduction in total lipids as observed in this study could explain because magnesium may impair the glucose uptake stimulated by insulin, in addition to reducing the concentration of lipids in the bloodstream (Günther, 2010). This mineral forms chelates with the free fatty acids, deviating them to be eliminated along with the feces, damaging indirectly the lipid synthesis in the tissues (Apple et al., 2000).

\subsection{Lipid profile}

The use of minerals showed effects on the meat lipid profile (Table 3), and in general, the group supplemented with $\mathrm{MgSe}$ showed a reduction in the levels of saturated fatty acids (SFA) $(\mathrm{p}=0.035)$ and increase in poly-unsaturated (PUFA) $(\mathrm{p}=0,009)$, when compared to the control group. The CrFe and $\mathrm{CrFeMgSe}$ groups showed intermediate values for these fatty acids summations. The use of MgSe in the finishing pigs' diets also promoted reduction of levels of myristic acid
$(\mathrm{C} 14: 0)(\mathrm{p}=0.003)$ and palmitic acid $(\mathrm{C} 16: 0)(\mathrm{p}=0.008)$ and increase in heptadecanoic acid $(\mathrm{C} 17: 1)(\mathrm{p}=0.013)$, linoleic acid $(\mathrm{C} 18: 2 n-6 c)(\mathrm{p}=0.008)$, eicosadienoic acid $(\mathrm{C} 20: 2 n-6)(\mathrm{p}=0.027)$, eicosatrienoic acid $(\mathrm{C} 20: 3 n-6)(\mathrm{p}=0.032)$, arachidonic acid $(\mathrm{C} 20: 4 n-6)(\mathrm{p}=0.030)$ and behenic acid $(\mathrm{C} 22: 0)(\mathrm{p}=0.031)$. The increase in the levels of these fatty acids, associated with an increase in the PUFA and reduction of C14:0 and C16:0, being these last two considered fatty atherogenic acids, contributed to the reduction in the atherogenicity rate, when compared to the control group. The magnesium deficiency was associated with a change in the atherogenic lipid composition of patients with heart disease (Rasmussen et al., 1989), and its use in diet caused an increase in the apoliprotein A: apoliprotein B, as a protective mechanism against atherosclerosis.

Still, higher levels of docosahexaenoic acid (DHA) $(\mathrm{p}=0.002)$, whereas the control group showed the lowest level. The docosahexaenoic acid (DHA) has beneficial effects on health including antiatherogenic, antithrombotic and anti-inflammatory action and its synthesis from $\alpha$-linolenic acid in adult humans is limited. The magnesium, due to being enzymes cofactor responsible for desaturation of long-chain fatty acids (Nakamura \& Nara, 2004), may have influenced the highest production of DHA. The other fatty acids were not influenced by the treatments applied.

The PUFA: SFA ratio was $43 \%$ higher for the group MgSe $(\mathrm{p}=0.007)$ as compared to the control group, while the groups $\mathrm{CrFe}$ and $\mathrm{CrFeMgSe}$ did not differ from the others. There was also an increase of $41 \%$ and $38 \%$ in the content of essential fatty acids $n-3(\mathrm{p}=0.018)$ and $n-6(\mathrm{p}=0.009)$, respectively, for the group that received $\mathrm{MgSe}$ when compared to the control group without, however, affecting the ratio $n-6: n-3$ and the other groups showed intermediate values.

The increase, particularly in the content of fatty acids $n-3$ in the meat is an aspect of paramount importance, due to its antithrombotic and anti-atheromatous role, contributing to the prevention of cardiovascular diseases. Thus, the pork due to being the largest source of animal protein consumed in the world, can contribute to the reduction of the ratio $n-6: n-3$ consumed. The increase in the content of essential fatty acids in the group supplemented with magnesium and selenium can be explained by the fact that the first is a cofactor for enzymes $\Delta 5$ and $\Delta 6$-desaturase, responsible for the reactions of long-chain fatty acids desaturation (Nakamura \& Nara, 2004). It was demonstrated that the magnesium deficiency led to a change in the rat's lipid profile, due to decreased activity of the enzyme $\Delta 6$-desaturase (Mahfouz \& Kummerow, 1989), showing its importance in lipid metabolism. Selenium deficiency also demonstrated to interfere in the rats' lipid profile, reducing the fatty acids $n-3$ and low levels of these have been associated with inhibition of the $\Delta 6$-desaturase activity, acting indirectly in the process of fatty acids oxygen desaturation, altering the lipid profile (Schäfer et al., 2004).

The activity of the enzyme Thioesterases $\mathrm{C}^{16-14}$ was higher $(\mathrm{p}=0.010)$ for MgSe regarding the control, and that the groups $\mathrm{CrFe}$ and $\mathrm{CrFeMgSe}$, showed similar averages to the others. In spite of the MgSe having presented a reduction of $3.6 \%$ in the level of $\mathrm{C} 16: 0$ as compared to the 
Table 3. Lipid profile of Longissimus thoracis (LT) muscle of finishing swines supplemented with different associations between minerals.

\begin{tabular}{|c|c|c|c|c|c|}
\hline \multirow{2}{*}{ Fatty acids } & \multicolumn{4}{|c|}{ Diets } & \multirow{2}{*}{$P$-value } \\
\hline & Control $^{1}$ & $\mathrm{CrFe}^{2}$ & $\mathrm{MgSe}^{3}$ & $\mathrm{CrFeMgSe}^{4}$ & \\
\hline C10:0 & $0.04 \pm 0.02$ & $0.05 \pm 0.02$ & $0.03 \pm 0.02$ & $0.04 \pm 0.02$ & 0.15 \\
\hline C12:0 & $0.11 \pm 0.04$ & $0.17 \pm 0.16$ & $0.11 \pm 0.09$ & $0.14 \pm 0.09$ & 0.78 \\
\hline C13:0 & $0.00 \pm 0.01$ & $0.01 \pm 0.05$ & $0.01 \pm 0.01$ & $0.01 \pm 0.01$ & 0.39 \\
\hline C14:0 & $1.14 \pm 0.12^{\mathrm{a}}$ & $1.03 \pm 0.11^{\mathrm{ab}}$ & $0.94 \pm 0.08^{\mathrm{b}}$ & $1.06 \pm 0.14^{\mathrm{ab}}$ & 0.01 \\
\hline C14:1 & $0.01 \pm 0.01$ & $0.01 \pm 0.01$ & $0.01 \pm 0.01$ & $0.01 \pm 0.01$ & 0.87 \\
\hline C15:0 & $0.05 \pm 0.02$ & $0.06 \pm 0.02$ & $0.07 \pm 0.03$ & $0.07 \pm 0.03$ & 0.41 \\
\hline C16:0 & $25.71 \pm 0.61^{\mathrm{a}}$ & $25.21 \pm 0.72^{\mathrm{ab}}$ & $24.75 \pm 0.38^{\mathrm{b}}$ & $25.36 \pm 0.84^{\mathrm{ab}}$ & 0.01 \\
\hline C16:1 & $2.73 \pm 0.47$ & $2.66 \pm 0.24$ & $2.42 \pm 0.30$ & $2.56 \pm 0.34$ & 0.22 \\
\hline $\mathrm{C} 17: 0$ & $0.27 \pm 0.07$ & $0.30 \pm 0.06$ & $0.33 \pm 0.09$ & $0.30 \pm 0.08$ & 0.30 \\
\hline C17:1 & $0.54 \pm 0.13^{\mathrm{b}}$ & $0.66 \pm 0.16^{\mathrm{ab}}$ & $0.76 \pm 0.13^{\mathrm{a}}$ & $0.69 \pm 0.16^{\mathrm{ab}}$ & 0.01 \\
\hline C18:0 & $11.79 \pm 1.20$ & $11.01 \pm 0.80$ & $11.23 \pm 0.75$ & $11.44 \pm 1.03$ & 0.22 \\
\hline C18:1n-9t & $0.12 \pm 0.01$ & $0.13 \pm 0.06$ & $0.16 \pm 0.09$ & $0.13 \pm 0.04$ & 0.65 \\
\hline C18:1 n-9c & $45.09 \pm 2.24$ & $43.37 \pm 2.51$ & $42.32 \pm 2.40$ & $43.24 \pm 2.78$ & 0.09 \\
\hline C18:2 $n-6 c$ & $9.19 \pm 1.92^{\mathrm{b}}$ & $11.35 \pm 1.85^{\mathrm{ab}}$ & $12.35 \pm 2.11^{\mathrm{a}}$ & $11.10 \pm 2.21^{\mathrm{ab}}$ & 0.09 \\
\hline C20:0 & $0.12 \pm 0.03$ & $0.10 \pm 0.12$ & $0.10 \pm 0.02$ & $0.11 \pm 0.02$ & 0.10 \\
\hline C18:3 n-6 & $0.05 \pm 0.01$ & $0.06 \pm 0.02$ & $0.06 \pm 0.01$ & $0.06 \pm 0.02$ & 0.08 \\
\hline C20:1 n-9 & $0.55 \pm 0.07$ & $0.50 \pm 0.08$ & $0.51 \pm 0.09$ & $0.49 \pm 0.08$ & 0.36 \\
\hline C18:3 n-3 & $0.09 \pm 0.02$ & $0.10 \pm 0.02$ & $0.10 \pm 0.03$ & $0.09 \pm 0.02$ & 0.43 \\
\hline C21:0 & $0.01 \pm 0.01$ & $0.01 \pm 0.01$ & $0.01 \pm 0.01$ & $0.01 \pm 0.01$ & 0.59 \\
\hline C20:2 n-6 & $0.19 \pm 0.04^{\mathrm{b}}$ & $0.22 \pm 0.03^{\mathrm{ab}}$ & $0.25 \pm 0.05^{\mathrm{a}}$ & $0.20 \pm 0.04^{\mathrm{ab}}$ & 0.03 \\
\hline C22:0 & $0.06 \pm 0.01^{\mathrm{b}}$ & $0.08 \pm 0.02^{\mathrm{ab}}$ & $0.09 \pm 0.02^{\mathrm{a}}$ & $0.08 \pm 0.03^{\mathrm{ab}}$ & 0.03 \\
\hline $\mathrm{C} 20: 3 n-6$ & $0.17 \pm 0.07$ & $0.24 \pm 0.08^{\mathrm{ab}}$ & $0.26 \pm 0.05^{\mathrm{a}}$ & $0.22 \pm 0.06^{\mathrm{ab}}$ & 0.03 \\
\hline C22:1 n-9 & $0.10 \pm 0.11$ & $0.07 \pm 0.05$ & $0.06 \pm 0.06$ & $0.12 \pm 0.08$ & 0.32 \\
\hline C20:3n-3 & $0.03 \pm 0.01$ & $0.03 \pm 0.01$ & $0.04 \pm 0.02$ & $0.03 \pm 0.01$ & 0.28 \\
\hline C20:4n-6 & $1.88 \pm 0.78^{\mathrm{b}}$ & $2.60 \pm 0.85^{\mathrm{ab}}$ & $2.92 \pm 0.64^{\mathrm{a}}$ & $2.47 \pm 0.84^{\mathrm{ab}}$ & 0.03 \\
\hline C20:5 n-3 & $0.04 \pm 0.03$ & $0.05 \pm 0.02$ & $0.06 \pm 0.02$ & $0.06 \pm 0.04$ & 0.17 \\
\hline $\mathrm{C} 22: 6 n-3$ & $0.02 \pm 0.01^{\mathrm{b}}$ & $0.03 \pm 0.01^{\mathrm{ab}}$ & $0.04 \pm 0.01^{\mathrm{a}}$ & $0.03 \pm 0.02^{\mathrm{ab}}$ & 0.01 \\
\hline \multicolumn{6}{|l|}{ Parameters } \\
\hline SFA & $39.35 \pm 1.74^{\mathrm{a}}$ & $38.08 \pm 1.42^{\mathrm{ab}}$ & $37.66 \pm 0.97^{\mathrm{b}}$ & $38.66 \pm 1.71^{\mathrm{ab}}$ & 0.04 \\
\hline MUFA & $49.02 \pm 2.43$ & $47.27 \pm 2.55$ & $46.07 \pm 2.52$ & $47.10 \pm 2.92$ & 0.09 \\
\hline PUFA & $11.78 \pm 2.79^{b}$ & $14.81 \pm 2.74^{\mathrm{ab}}$ & $16.23 \pm 2.77^{\mathrm{a}}$ & $14.39 \pm 3.15^{\mathrm{ab}}$ & 0.01 \\
\hline$\sum n-3$ & $0.17 \pm 0.03^{\mathrm{b}}$ & $0.21 \pm 0.04^{\mathrm{ab}}$ & $0.24 \pm 0.04^{\mathrm{a}}$ & $0.22 \pm 0.07^{\mathrm{ab}}$ & 0.02 \\
\hline$\sum n-6$ & $11.48 \pm 2.76^{\mathrm{b}}$ & $14.47 \pm 2.71^{\mathrm{ab}}$ & $15.83 \pm 2.70^{\mathrm{a}}$ & $14.04 \pm 3.09^{\mathrm{ab}}$ & 0.01 \\
\hline$\sum n-6 / \sum n-3$ & $67.32 \pm 9.89$ & $68.73 \pm 12.15$ & $67.19 \pm 9.34$ & $66.22 \pm 11.97$ & 0.96 \\
\hline PUFA/SFA & $0.30 \pm 0.08^{\mathrm{b}}$ & $0.39 \pm 0.08^{\mathrm{ab}}$ & $0.43 \pm 0.09^{\mathrm{a}}$ & $0.38 \pm 0.09^{\mathrm{ab}}$ & 0.01 \\
\hline$\Delta 9$-desaturase C16 & $9.54 \pm 1.58$ & $9.53 \pm 0.73$ & $8.93 \pm 1.01$ & $9.14 \pm 1.16$ & 0.50 \\
\hline$\Delta 9$-desaturase C18 & $79.22 \pm 1.86$ & $79.78 \pm 1.47$ & $79.08 \pm 1.23$ & $78.99 \pm 2.02$ & 0.62 \\
\hline Elongase C16-C18 & $66.64 \pm 0.89$ & $66.09 \pm 1.16$ & $66.30 \pm 1.12$ & $66.15 \pm 1.09$ & 0.64 \\
\hline Thioesterase C16-14 & $95.77 \pm 0.32^{\mathrm{b}}$ & $96.08 \pm 0.40^{\mathrm{ab}}$ & $96.34 \pm 0.27^{\mathrm{a}}$ & $96.01 \pm 0.44^{\mathrm{ab}}$ & 0.01 \\
\hline Atherogenicity & $0.59 \pm 0.04^{\mathrm{a}}$ & $0.56 \pm 0.03^{\mathrm{ab}}$ & $0.53 \pm 0.03^{b}$ & $0.56 \pm 0.04^{\mathrm{ab}}$ & 0.01 \\
\hline Thrombogenicity & $0.40 \pm 0.05$ & $0.38 \pm 0.05$ & $0.38 \pm 0.04$ & $0.40 \pm 0.05$ & 0.66 \\
\hline Cholesterol (mg/100g) & $75.41 \pm 23.30$ & $118.14 \pm 27.84$ & $101.83 \pm 22.21$ & $101.88 \pm 22.31$ & 0.52 \\
\hline
\end{tabular}

${ }^{1}$ Control: basal diet; ${ }^{2} \mathrm{CrFe}$ : supplementation with chromium and iron; ${ }^{3} \mathrm{MgSe}$ : supplementation with magnesium and selenium; ${ }^{4} \mathrm{CrFeMgSe}$ supplementation with chromium, iron, magnesium and selenium; SFA: total of saturated fatty acids; MUFA: total of monounsaturated fatty acids; PUFA: total of unsaturated fatty acids; PUFA/SFA: unsaturated: saturated ratio; ${ }^{5}$ Tukey's test $(\alpha=0.05)$. Number of replicates per parameters $=11$. a,b,c: Different letters indicate statistically significant differences between treatments.

control group, there was also a more pronounced reduction of C14:00 (17.22\%), which increased the ratio C16:0:C14:0. There was a reduction $(p=0.002)$ in the atherogenicity index of $10.6 \%$ for the meat of those animals supplemented with $\mathrm{MgSe}$, when compared to the control group, while the other groups showed intermediate values. The atherogenicity and thrombogenicity indexes indicate the potential to stimulate platelet aggregation, being that the lower their values means that the tissue (fat and/or meat) has a better profile of antiatherogenic fatty acids, having then, increased capacity for prevention of coronary heart disease (Arruda et al., 2012). Thus, the reduction in the atherogenicity index in the meat of those animals that received MgSe demonstrated that supplementation resulted in a meat with lipid profile more beneficial to health. The thrombogenicity index, however, showed similar values for all treatments. 
The cholesterol levels ranged from 73.97 to 116.88 (mean of $98.08 \mathrm{mg} / 100 \mathrm{~g}$ of meat), not being altered by supplementation with minerals used and getting close to those obtained by Faria et al. (2015) (84.76 mg/100g).

\subsection{Display life}

The color parameters evaluated during the storage time at $4{ }^{\circ} \mathrm{C}$, were affected by the treatments with minerals, although interaction between the diets and the time was not observed (Table 4). The values of $\mathrm{a}^{*}(\mathrm{p}=0.001)$ and $\mathrm{b}^{*}(\mathrm{p}=0.001)$ were higher in the group CrFeMgSe and lower for MgSe. The control group and the CrFe did not differ among themselves, being that the first had a mean similar to CrFeMgSe and the second a mean similar to MgSe. There was a reduction of $C^{\star}(p=0.001)$ for $\mathrm{CrFe}$ and $\mathrm{MgSe}$ compared with the control group and the latter had mean similar to $\mathrm{CrFeMgSe}$. On the contrary, $\mathrm{CrFe}$ and MgSe presented higher values for $h^{\star}(p=0.003)$ compared to the control and CrFeMgSe, being that these last two did not differ among themselves. There was no influence of minerals in $L^{*}$.
These results are in disagreement with the studies of Frederick et al. (2004) who observed no influence of magnesium supplied through drinking water during 6 days before slaughter, in the parameters $\mathrm{a}^{*}$ and $\mathrm{b}^{*}$ of pork stored at $4^{\circ} \mathrm{C}$ during 8 days. However, these same authors did not also observe effect of the mineral in $\mathrm{L}^{*}$ as well as in the present study. Regarding the effect of iron, Wallis et al. (2003) did not observe any change in $\mathrm{L}^{*}, \mathrm{a}^{*}, \mathrm{~b}^{*}, \mathrm{C}^{\star}$ and $\mathrm{h}^{\star}$ when they used different concentrations of organic iron, contradicting the findings of the present study, except for the $\mathrm{L}^{*}$ that was also not changed by the treatments. Jin et al. (2018) also did not observe the effect of chromium methionine $(200 \mu \mathrm{g} / \mathrm{kg})$ in parameters of color. On the other hand, Khan, et al. (2018), using $0.3 \mathrm{mg} / \mathrm{kg}$ of sodium selenite, observed increased in $\mathrm{a}^{*}$ and $\mathrm{b}^{*}$ in poultry, in discordance with our finds.

There was also an influence of time on the color parameters (Table 4$)$ with linear drop to $\mathrm{L}^{*}(\mathrm{p}=0.011)$ and $\mathrm{a}^{*}(\mathrm{p}<0.001)$ and linear increase for $h^{\star}(p<0.001)$ (Figure 1). There was no effect of storage time in $\mathrm{b}^{\star}$ and $\mathrm{C}^{\star}$.

Table 4. Color and percentage of pigments of Longissimus thoracis (LT) muscle of finishing swines supplemented with different associations between minerals, stored at $4{ }^{\circ} \mathrm{C}$ for six days.

\begin{tabular}{|c|c|c|c|c|c|c|c|}
\hline \multirow{2}{*}{ Parameter } & \multicolumn{4}{|c|}{ Diets (D) } & \multicolumn{3}{|c|}{$P$-value ${ }^{5}$} \\
\hline & Control $^{1}$ & $\mathrm{CrFe}^{2}$ & $\mathrm{MgSe}^{3}$ & $\mathrm{CrFeMgSe}^{4}$ & $\mathrm{D}$ & $\mathrm{T}$ & $\mathrm{D} \times \mathrm{T}$ \\
\hline \multicolumn{8}{|l|}{ Color } \\
\hline$L^{*}$ & $56.26 \pm 3.18$ & $55.47 \pm 4.89$ & $54.40 \pm 6.97$ & $56.68 \pm 2.68$ & 0.09 & 0.01 & 1.00 \\
\hline$a^{*}$ & $0.74 \pm 0.90^{\mathrm{ab}}$ & $0.31 \pm 0.94^{\mathrm{bc}}$ & $0.21 \pm 0.32^{c}$ & $1.18 \pm 0.69^{\mathrm{a}}$ & 0.01 & 0.01 & 0.95 \\
\hline$b^{*}$ & $10.34 \pm 1.01^{\mathrm{ab}}$ & $9.78 \pm 0.99^{\mathrm{bc}}$ & $9.31 \pm 1.42^{\mathrm{c}}$ & $10.37 \pm 0.89^{\mathrm{a}}$ & 0.01 & 0.07 & 0.10 \\
\hline $\mathrm{C}^{*}$ & $10.46 \pm 0.96^{\mathrm{a}}$ & $9.88 \pm 0.90^{\mathrm{b}}$ & $9.36 \pm 1.48^{\mathrm{b}}$ & $10.51 \pm 0.89^{\mathrm{a}}$ & 0.01 & 0.07 & 0.99 \\
\hline$h^{*}$ & $86.05 \pm 5.36^{\mathrm{b}}$ & $88.35 \pm 5.60^{\mathrm{a}}$ & $88.87 \pm 2.18^{\mathrm{a}}$ & $85.50 \pm 3.97^{b}$ & 0.01 & 0.01 & 0.99 \\
\hline \multicolumn{8}{|l|}{$\%$ Pigments } \\
\hline $\mathrm{O}_{2} \mathrm{Mb}$ & $48.59 \pm 2.56$ & $46.02 \pm 3.16$ & $46.21 \pm 3.78$ & $47.40 \pm 4.01$ & 0.31 & 0.01 & 0.73 \\
\hline $\mathrm{MMb}$ & $34.00 \pm 1.85$ & $33.90 \pm 3.79$ & $33.35 \pm 4.25$ & $33.66 \pm 2.24$ & 0.73 & 0.01 & 0.70 \\
\hline $\mathrm{Mb}^{+}$ & $17.31 \pm 3.99$ & $20.11 \pm 6.58$ & $20.52 \pm 7.96$ & $18.90 \pm 5.93$ & 0.52 & 0.01 & 0.97 \\
\hline
\end{tabular}

${ }^{1}$ Control: basal diet; ${ }^{2} \mathrm{CrFe}$ : supplementation with chromium and iron; ${ }^{3} \mathrm{MgSe}$ : supplementation with magnesium and selenium; ${ }^{4} \mathrm{CrFeMgSe}$ supplementation with chromium, iron, magnesium and selenium; T: time; $\mathrm{D} \times \mathrm{T}$ : Interaction between diet and time; $\mathrm{L}^{*}$ : lightness; $\mathrm{a}^{*}$ : redness; $\mathrm{b}^{*}$ yellowness; $\mathrm{C}^{*}$ : Chroma; $\mathrm{h}^{*}$ : hue angle; $\mathrm{O}_{2} \mathrm{Mb}$ : oxymyoglobin; $\mathrm{MMb}$ : metmyoglobin; $\mathrm{Mb}^{+}$: reduced myoglobin. ${ }^{5}$ Tukey's test $(\alpha=0.05)$. Number of replicates per parameters $=11$. a,b,c, Different letters indicate statistically significant differences between treatments.

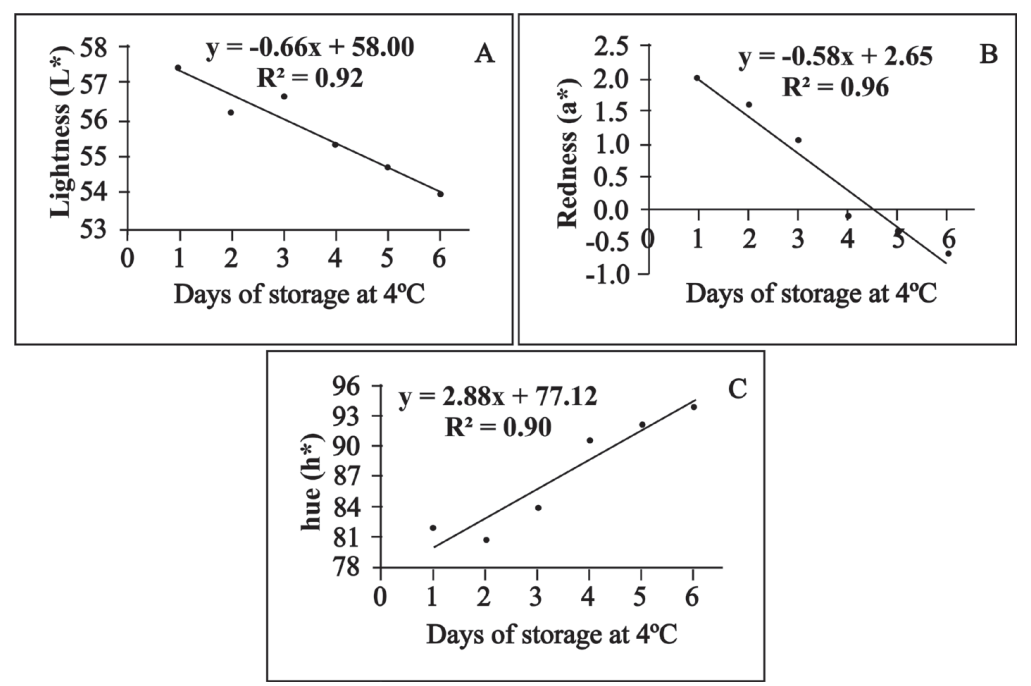

Figure 1. Regression equations for lightness (A), redness (B) and hue angle (C) of LT muscle of finishing swines supplemented with different mineral associations stored at $4{ }^{\circ} \mathrm{C}$ for six days. ${ }^{*}$ : CIELAB System. 


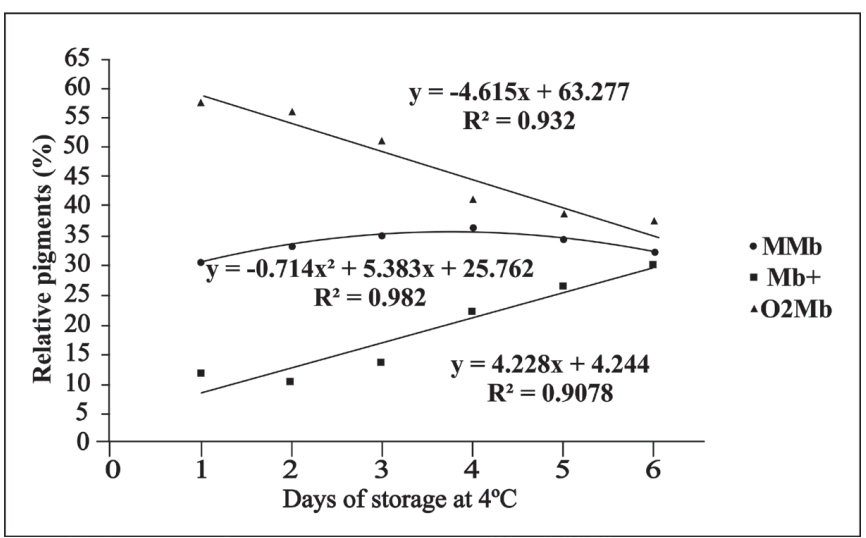

Figure 2. Regression equations for the relative percentage of metmyoglobin $(\mathrm{MMb})$, reduced myoglobin $\left(\mathrm{Mb}^{+}\right)$and oxymyoglobin $(\mathrm{O} 2 \mathrm{Mb})$ of the LT muscle of finishing swines supplemented with different mineral associations, stored at $4{ }^{\circ} \mathrm{C}$ for six days.

The reduction in the values of $\mathrm{L}^{*}$ concomitantly with the increase of $h^{\star}$ indicates that there was oxidation of the pigment myoglobin (Haile et al., 2013). This is observed when analyzing the changes in the levels of pigments for the storage period (Figure 2), where we can observe a reduction in the content of oxymyoglobin and increase of metmyoglobin. The myoglobin oxidation with formation of metmyoglobin, which features brownish color was favored by the contact of the meat with the oxygen from the environment. Still, the presence of light and the meat lipid oxidation also favors a higher myoglobin oxidation (Haile et al., 2013).

\section{Conclusion}

Thus, the use of magnesium and selenium associated reduces the amount of lipids, promoting an improvement in pig meat lipid profile for human consumption, without negative effects on the quality and its conservation, and it can be used as a tool to improve the nutritional aspects of pork.

\section{Acknowledgements}

This work was funded by the Brazilian institutions: Coordenação de Aperfeiçoamento de Pessoal de Nível Superior (CAPES), Fundação de Amparo à Pesquisa do Estado de Minas Gerais (FAPEMIG) and the Núcleo de Pesquisas Aplicadas Ltda (NPA).

\section{References}

Apple, J. K., Maxwell, C. V., Rodas, B., Watson, H. B., \& Johnson, Z. B. (2000). Effect of magnesium mica on performance and carcass quality of growing-finishing swine. Journal of Animal Science, 78(8), 2135-2143. http://dx.doi.org/10.2527/2000.7882135x. PMid:10947100.

Apple, J. K., Wallis-Phelps, W. A., Maxwell, C. V., Rakes, L. K., Sawyer, J. T., Hutchison, S., \& Fakler, T. M. (2007). Effect of supplemental iron on finishing swine performance, carcass characteristics, and pork quality during retail display. Journal of Animal Science, 85(3), 737-745. http://dx.doi.org/10.2527/jas.2006-231. PMid:17085730.

Arruda, P. C. L., Pereira, E. S., Pimentel, P. G., Bomfim, M. A. D., Mizubuti, I. Y., Ribeiro, E. L. A., Fontenele, R. M., \& Regadas, J. G. L.
Fo. (2012). Perfil de ácidos graxos no Longissimus dorsi de cordeiros Santa Inês alimentados com diferentes níveis energéticos. Semina: Ciências Agrárias, 33(3), 1229-1240. http://dx.doi.org/10.5433/16790359.2012v33n3p1229.

Bragagnolo, N., \& Rodriguez-Amaya, D. B. (2002). Teores de colesterol, lipídios totais e ácidos graxos em cortes de carne suína. Food Science and Technology (Campinas), 22(1), 98-104. http://dx.doi.org/10.1590/ S0101-20612002000100018.

Calvo, L., Toldrá, F., Aristoy, M. C., López-Bote, C. J., \& Rey, A. I. (2016). Effect of dietary organic selenium on muscle proteolytic activity and water-holding capacity in pork. Meat Science, 121, 1-11. http://dx.doi.org/10.1016/j.meatsci.2016.05.006. PMid:27232379.

Faria, P. B., Cantarelli, V. S., Fialho, E. T., Pinto, A. M. B. G., Faria, J. H., Rocha, M. F. M., Guerreiro, M. C., \& Bressan, M. C. (2015). Lipid profile and cholesterol of pork with the use of glycerin in feeding. Arquivo Brasileiro de Medicina Veterinária e Zootecnia, 67(2), 535546. http://dx.doi.org/10.1590/1678-7112.

Folch, J., Lees, M., \& Sloane Stanley, G. H. (1957). A simple method for the isolation and purification of total lipids from animal tissues. The Journal of Biological Chemistry, 226(1), 497-509. PMid:13428781.

Food and Agriculture Organization of United Nations. (2010). Fats and fatty acids in human nutrition (vol. 91). Rome: FAO.

Frederick, B. R., Van Heugten, E., \& See, M. T. (2004). Timing of magnesium supplementation administered through drinking water to improve fresh and stored pork quality. Journal of Animal Science, 82(5), 1454-1460. http://dx.doi.org/10.2527/2004.8251454x. PMid:15144086.

Frederick, B. R., Van Heugten, E., Hanson, D. J., \& See, M. T. (2006). Effects of supplemental magnesium concentration of drinking water on pork quality. Journal of Animal Science, 84(1), 185-190. http:// dx.doi.org/10.2527/2006.841185x. PMid:16361506.

Günther, T. (2010). The biochemical function of $\mathrm{Mg}^{2}+$ in insulin secretion, insulin signal transduction and insulin resistance. Magnesium Research, 23(1), 5-18. PMid:20228013.

Haile, D. M., Smet, S., Claeys, E., \& Vossen, E. (2013). Effect of light, packaging condition and dark storage durations on colour and lipid oxidative stability of cooked ham. Journal of Food Science and Technology, 50(2), 239-247. http://dx.doi.org/10.1007/s13197-0110352-x. PMid:24425913.

Hartman, L., \& Lago, R. C. (1973). Rapid preparation to fatty acids methyl esters from lipids. Laboratory Practice, 22(6), 475-476. PMid:4727126.

Honikel, K. O. (1998). Reference methods for the assessment of physical characteristics of meat. Meat Science, 49(4), 447-457. http://dx.doi. org/10.1016/S0309-1740(98)00034-5. PMid:22060626.

Horwitz, W. (1990). Official Methods of Analysis of Association of Official Analytical Chemists (13th ed). Washington: AOAC.

Jeong, D. W., Kim, E. H., Kim, T. S., Chung, Y. W., Kim, H., \& Kim, I. Y. (2004). Different distributions of selenoprotein $\mathrm{W}$ and thioredoxin during postnatal brain development and embryogenesis. Molecules and Cells, 17(1), 156-159. PMid:15055543.

Jin, C. L., Wang, Q., Zhang, Z. M., Xu, Y. L., Yan, H. C., Li, H. C., Gao, C. Q., \& Wang, X. Q. (2018). Dietary supplementation with pioglitazone hydrochloride and chromium methionine improves growth performance, meat quality, and antioxidant ability in finishing pigs. Journal of Agricultural and Food Chemistry, 66(17), 4345-4351. http://dx.doi.org/10.1021/acs.jafc.8b01176. PMid:29682966.

Kazala, E. C., Lozeman, F. J., Mir, P. S., Laroche, A., Bailey, D. R. C., \& Weselake, R. J. (1999). Relationship of fatty acid composition to intramuscular fat content in beef from crossbred wagyu 
cattle. Journal of Animal Science, 77(7), 1717-1725. http://dx.doi. org/10.2527/1999.7771717x. PMid:10438017.

Khan, A. Z., Kumbhar, S., Liu, Y., Hamid, M., Pan, C., Nido, S. A., Parveen, F., \& Huang, K. (2018). Dietary supplementation of selenium-enriched probiotics enhances meat quality of broiler chickens (Gallus gallus domesticus) raised under high ambient temperature. Biological Trace Element Research, 182(2), 328-338. http://dx.doi.org/10.1007/s12011-017-1094-z. PMid:28702872.

Krzywicki, K. (1979). Assessment of relative content of myoglobin, oxymyoglobin and metmyoglobin at the surface of beef. Meat Science, 3(1), 1-10. http://dx.doi.org/10.1016/0309-1740(79)900196. PMid:22055195.

Li, J. G., Zhou, J. C., Zhao, H., Lei, X. G., Xia, X. J., Gao, G., \& Wang, K. N. (2011). Enhanced water-holding capacity of meat was associated with increased Sepw1 gene expression in pigs fed selenium-enriched yeast. Meat Science, 87(2), 95-100. http://dx.doi.org/10.1016/j. meatsci.2010.05.019. PMid:20558011.

Lisiak, D., Janiszewski, P., Blicharski, T., Borzuta, K., Grześkowiak, E., Lisiak, B., Powałowski, K., Samardakiewicz, Ł., Batorska, M., Skrzymowska, K., \& Hammermeister, A. (2014). Effect of selenium supplementation in pig feed on slaughter value and physicochemical and sensory characteristics of meat. Annals of Animal Science, 14(1), 213-222. http://dx.doi.org/10.2478/aoas-2013-0063.

Mahfouz, M. M., \& Kummerow, F. A. (1989). Effect of magnesium deficiency on delta 6 desaturase activity and fatty acid composition of rat liver microsomes. Lipids, 24(8), 727-732. http://dx.doi. org/10.1007/BF02535212. PMid:2555646.

Malau-Aduli, A. E. O., Siebert, B. D., Bottema, C. D. K., \& Pitchford, W. S. (1998). Breed Comparison of the Fatty Acid Composition of Muscle Phospholipids in Jersey and Limousin Cattle. Journal of Animal Science, 76(3), 766-773. http://dx.doi.org/10.2527/1998.763766x. PMid:9535336.

Nakamura, M. T., \& Nara, T. Y. (2004). Structure, function, and dietary regulation of $\Delta 6, \Delta 5$, and $\Delta 9$ desaturases. Annual Review of Nutrition, 24(1), 345-376. http://dx.doi.org/10.1146/annurev. nutr.24.121803.063211. PMid:15189125.

National Pork Producers Council. (1999). Pork Quality Standards National Pork Board. Des Moines: NPPC.

Peres, L. M., Bridi, A. M., Silva, C. A., Andreo, N., Barata, C. C. P., \& Dário, J. G. N. (2014). Effect of supplementing finishing pigs with different sources of chromium on performance and meat quality. Revista Brasileira de Zootecnia, 43(7), 369-375. http://dx.doi. org/10.1590/S1516-35982014000700005.

Ramos, E. M., \& Gomide, L. A. M. (2012). Avaliação da qualidade de carnes: fundamentos e metodologias. Viçosa: Editora UFV.
Rasmussen, H. S., Aurup, P., Goldstein, K., McNair, P., Mortensen, P. B., Larsen, O. G., \& Lawaetz, H. (1989). Influence of magnesium substitution therapy on blood lipid composition in patients with ischemic heart disease. Archives of Internal Medicine, 149(5), 10501053. http://dx.doi.org/10.1001/archinte.1989.00390050052010. PMid:2719498.

Schäfer, K., Kyriakopoulos, A., Gessner, H., Grune, T., \& Behne, D. (2004). Effects of selenium deficiency on fatty acid metabolism in rats fed fish oil-enriched diets. Journal of Trace Elements in Medicine and Biology, 18(1), 89-97. http://dx.doi.org/10.1016/j. jtemb.2004.03.003. PMid:15487769.

Silva, D. R. G., Torres, R. A. Fo., Cazedey, H. P., Fontes, P. R., Ramos, A. L. S., \& Ramos, E. M. (2015). Comparison of Warner-Bratzler shear force values between round and square cross-section cores from cooked beef and pork Longissimus muscle. Meat Science, 103, 1-6. http://dx.doi.org/10.1016/j.meatsci.2014.12.009. PMid:25569815.

Swigert, K. S., McKeith, F. K., Carr, T. C., Brewer, M. S., \& Culbertson, M. (2004). Effects of dietary vitamin D3, vitamin E, and magnesium supplementation on pork quality. Meat Science, 67(1), 81-86. http:// dx.doi.org/10.1016/j.meatsci.2003.09.008. PMid:22061119.

Tarsitano, M. A., Bridi, A. M., Silva, C. A., Constantino, C., Andreo, N., \& Dalto, D. B. (2013). Magnesium supplementation in swine finishing stage: performance, carcass characteristics and meat quality. Semina: Ciências Agrárias, 34(6), 3105-3118. http://dx.doi. org/10.5433/1679-0359.2013v34n6p3105.

Ulbricht, T. L. V., \& Southgate, D. A. T. (1991). Coronary heart disease: seven dietary factors. Lancet, 338(8773), 985-992. http://dx.doi. org/10.1016/0140-6736(91)91846-M. PMid:1681350.

United States Department of Agriculture. (2018). Livestock and poultry: world markets and trade. Washington: Foreign Agricultural Service. Retrieved from: https://apps.fas.usda.gov/psdonline/circulars/ livestock_poultry.pdf

Wallis, W. A., Apple, J. K., Maxwell, C. V., Rakes, L. K., Hutchison, S., \& Stephenson, J. D. (2003). Effects of iron supplementation level in diets of growing-finishing swine. II. Pork quality traits during retail display (Report). Arkansas: Arkansas Animal Science Department.

Wojtasik-Kalinowska, I., Guzek, D., Górska-Horczyczak, E., Brodowska, M., Sun, D. W., \& Wierzbicka, A. (2018). Diet with linseed oil and organic selenium yields low $n-6 / n-3$ ratio pork Semimembranosus meat with unchanged volatile compound profiles. International Journal of Food Science \& Technology, 53(8), 1838-1846. http:// dx.doi.org/10.1111/ijfs.13763.

Yu, B., Huang, W. J., \& Chiou, P. W. S. (2000). Bioavailability of iron from amino acid complex in weanling pigs. Animal Feed Science and Technology, 86(1-2), 39-52. http://dx.doi.org/10.1016/S03778401(00)00154-1. 